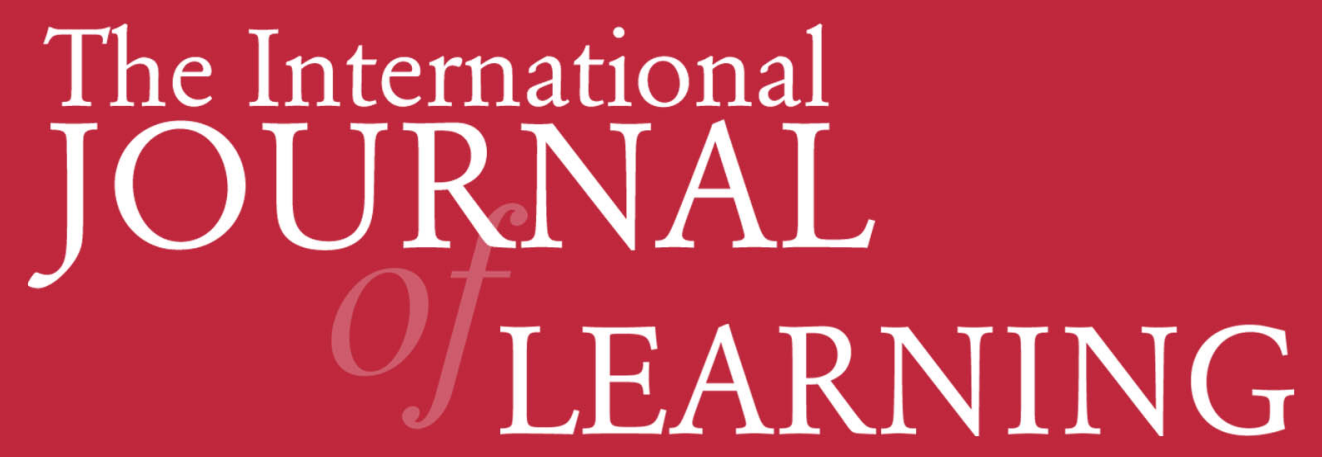

Teaching and evaluation methods preferred by university students

Fernando Justicia Justicia Jesús de la Fuente Arias M .Carmen Pichardo Martinez Ana Belen Garcia Berben 


\section{INTERNATIONAL JOURNAL OF LEARNING}

http://www.Learning-Journal.com

First published in 2005/2006 in Melbourne, Australia by Common Ground Publishing Pty Ltd www.CommonGroundPublishing.com.

(C) 2005/2006 (this paper), the author(s)

(C) 2005/2006 (selection and editorial matter) Common Ground

All rights reserved. Apart from fair use for the purposes of study, research, criticism or review as permitted under the Copyright Act (Australia), no part of this work may be reproduced without written permission from the publisher. For permissions and other inquiries, please contact <cg-support@commongroundpublishing.com>.

ISSN: 1447-9494 (print), 1447-9540 (online)

Publisher Site: http://www.Learning-Journal.com

The INTERNATIONAL JOURNAL OF LEARNING is a peer refereed journal. Full papers submitted for publication are refereed by Associate Editors through anonymous referee processes.

Typeset in Common Ground Markup Language using CGCreator multichannel typesetting system http://www.CommonGroundSoftware.com. 


\title{
Teaching and evaluation methods preferred by university students
}

\author{
Fernando Justicia Justicia, University of Granada, Spain \\ Jesús de la Fuente Arias, Universidad de Almería, Spain \\ M .Carmen Pichardo Martinez, University of Granada, Spain \\ Ana Belen Garcia Berben, Universidad de Granada, Spain
}

\begin{abstract}
Student preferences and expectations regarding university instruction are increasingly considered as quality indicators in higher education. In this study we investigate university students' expectations and preferences concerning the teaching process, and we perform a differential study based on variables pertaining to the individual student (gender and age) and to the teacher (gender). 249 students from the Faculty of Education at the University of Granada participated in this study. Expectations and preferences are measured using the USET questionnaire (Sander, Stevenson, King \& Coates, 2000). Results show that students wish to play a more active role in their learning. The formal lecture is the method most expected, and at the same time, the one most rejected, by more than half the sample. Variables analysed show significant differences in several teaching and evaluation methods.
\end{abstract}

Keywords: Expectations, Teaching Methods, Evaluation, University

\section{Expectations of University Teaching}

$\mathrm{F}$ IOR SOME YEARS now, social changes, university classroom characteristics and the high rate of failure and attrition which are observed in university education have pointed to the need for reform and improvement in Higher Education. On one hand, Spanish universities are implementing initiatives for quality improvement, oriented mainly toward improvements in teaching and in preparation of teachers and students. On the other hand, joining the European Space for Higher Education (ESHE) is an effort towards renewal of theory and practice in the teaching-learning process. The new process is directly mainly toward getting the university student to learn how to learn.

This fact implies a redefinition of traditional roles assigned to teachers and students. The teacher must move from playing a vital role of transmitting content to occupy a more supervisory role, mediating and facilitating learning. The student must take on a more active role in his or her learning. The new conception of the teaching-learning process in higher education has been studied and formulated by several authors (Biggs, 2001; Entwistle, 2000; Vermetten, Vermunt \& Lodewijks, 2002). Explanatory models and the theoretical framework they put forward are characterized mainly by studying the teaching-learning process from the perspective of the agents involved, that is, the teachers and the students. However, this research has paid little attention to student expectations.
Authors that have researched student expectations regarding the university in general, and regarding teaching in particular, express the need for and importance of understanding such expectations in order to improve the teaching-learning process (DarlastonJones, Pike, Cohen, Young, Haunold, \& Drew 2003; De la Fuente, Justicia, Sander, Cano, Martínez \& Pichardo, 2004a; De la Fuente, Justicia, Sander, Cano, Martínez \& Pichardo, 2004b; James, 2001; Keogh \& Stevenson, 2001; Sander et al., 2000; Sander, 2005).

Keith Stevenson at the University of Leicester and Paul Sander at the University of Wales Institute at Cardiff have studied expectations of university students from Psychology and Pedagogy. These researchers propose the Expectation Led Planned Organisation (ELPO) model. The ELPO model is used for designing teaching-learning programs based on student expectations. This model seeks to have teachers consider students' expectations before beginning the course, and to negotiate with them the most effective teaching-learning methods (Stevenson, Sander \& Naylor, 1997). Authors of this model have constructed an instrument which allows for quick and easy information retrieval, namely, University Students' Expectations of Teaching (USET).

In this framework, the authors (Sander et al., 2000) defend that student expectations and preferences regarding instruction provide valuable information to institutions of higher education for two reasons:

- Students who are starting out may have unrealistic expectations as to the teaching they will re- 
ceive, implying a need to reorient expectations toward more realistic ideas which are in line with higher education.

- Based on an understanding of their students' expectations and preferences, teachers could provide a more effective and gratifying educational service for their students.

\section{Studies regarding Expectations of Teaching}

Research arising from postulates similar to those of the ELPO model have been essential descriptive in character (De la Fuente et al., 2004b; Keogh \& Stevenson, 2001; Stevenson \& Sander, 1998; Sander et al., 2000; Yanhong \& Kaye, 1999), and have focused on relationships between expectations of teaching and certain contextual and academic variables such as nationality, the university, degree program or year of study (De la Fuente et al., 2004a). In this type of study there are few data about individual variables (such as gender and age) and their relationship to expectations of teaching.

In Spain, research led by De la Fuente (De la Fuente et al., 2004a and b) stems from postulates by Stevenson and Sander, and has analyzed expectations in samples of Spanish students (Psychology and Education programs at the Universities of Almeria and Granada) and British students (Psychology, Education and Medicine, at the Universities of Leigcs, Lough and UWIC, Wales). Data were obtained through the USET questionnaire. Conclusions indicate differences in expectations as a function of nationality and of the University in question.

Influence of student gender on teacher perceptions and expectations has already been investigated. McDowell and McDowell (1986) indicate that female students expect attentive teachers, with greater sensitivity and interest in the students, and who relate more closely to the students. Male students, by contrast, expect a more direct communicative style, expect to be criticized negatively, and that teachers will be impersonal and distant. Smith, Medendorp, Ranck, Morison and Kopfman (1994) conclude that female students are more sensitive to personal characteristics of teachers, while male students are more sensitive to the teacher's knowledge and sense of humor. Finally, we must consider that some research finds no differences in expectations as a function of student gender, but they highlight the importance of and need to continue analyzing the influence of the gender variable (Miles \& Gonsalves, 2003). The present study, therefore, seeks to understand whether student gender does influence expectations regarding teachers and other variables in the teaching process (teaching and evaluation methods).

Other research has been interested in student expectations as a function of the teacher's gender, although these studies focus on teacher qualities and do not consider the effect of expectations on teaching and evaluation methods. Thus, Ruzich (1995) concludes in her study that student expectations with regard to female and male teachers have hardly changed in recent years. Her results show that students expect female teachers to be more accessible, understanding, and permissive than male teachers. Elsewhere, Anderson and Miller (1997), cited in Chonko, Tanner and Davis (2003), demonstrate the need for continued research in this line of work, since different student expectations with regard to female and male teachers affect student responses.

Research reviewed is not in agreement as to the stability of expectations over time. While studies based on the ELPO model defend that expectations are stable, other studies indicate that the university experience influences and modifies expectations over time (Licata \& Maxham, 1999). This study seeks to examine age differences and their relationship to expectations, for the purpose of contributing more evidence for stability of expectations.

It is important to understand student expectations and preferences in order to have influence on those that show resistance to change, or to modify those which are false and provoke dissatisfaction in students on account of the teaching they receive (Chonko et al., 2002, Stevenson et al., 1997; Sander et al., 2000 y Sander, 2005). It is equally important to determine whether variables such as age and gender influence expectations, so we can better understand characteristics of the variable under study (expectations) and contribute useful information toward its consideration and management.

\section{Objectives}

1. Explore university students' expectations of teaching.

2. Analyze the influence of personal student variables (gender and age) and a personal teacher variable (gender) on student expectations about teaching.

\section{Participants}

The sample was composed of 294 students in Education or Educational Psychology programs at the University of Granada. $78.9 \%(\mathrm{~N}=232)$ of the participants were women and the rest were men $(21.1 \%$; $\mathrm{N}=62$ ). Age of participants ranged from 17 to 47 years, average age in the sample was 22 years $(\mathrm{SD}=4.25) .38 .1 \%(\mathrm{~N}=112)$ of students were taught by a female teacher, while $61.9 \%(\mathrm{~N}=182)$ received instruction from a male teacher.

\section{Instrument}

The instrument used was the Cuestionario sobre las expectativas de enseñanza de los estudiantes uni- 
versitarios (De la Fuente, Nievas \& Rius, 2002), the Spanish version of the USET questionnaire (University Students' Expectations of Teaching, Sander et al., 2000). The questionnaire has an instruction page where participants' personal data are requested. The questionnaire contains three sections. Section A presents 9 possible teaching methods and their definition (annex), and students are asked to mark, from greater to lesser (3 to 1), the three most desirable methods, the three most expected methods, and the three least desirable. In Section B students must rate the three most effective evaluation methods, using the same scoring system. In Section C students place in order, from greater to lesser importance (1 to 5), the four qualities they consider to be essential in a good teacher.

USET authors study validity using a correlation that contrasts desirable teaching methods with undesirable ones. The validity study for our data is shown in Table 1, where we present significant correlations that were found between desirable and undesirable teaching methods. It is easily observed that the most desirable teaching methods are those that least appear as undesirable.

Table1: Correlations between desirable and undesirable teaching methods $(p<0,01: * * ; p<0,05: *)$

\begin{tabular}{|l|l|l|l|l|l|l|l|l|l|}
\hline $\begin{array}{l}\text { Undesirable } \\
\text { Desirable }\end{array}$ & $\begin{array}{l}\text { Formal } \\
\text { lecture }\end{array}$ & $\begin{array}{l}\text { Inter-act- } \\
\text { ive } \\
\text { lecture }\end{array}$ & $\begin{array}{l}\text { Student- } \\
\text { centered } \\
\text { teaching }\end{array}$ & $\begin{array}{l}\text { Student } \\
\text { presenta- } \\
\text { tions }\end{array}$ & $\begin{array}{l}\text { T. ar. } \\
\text { group } \\
\text { work }\end{array}$ & $\begin{array}{l}\text { Tuto-ri- } \\
\text { als }\end{array}$ & $\begin{array}{l}\text { Group } \\
\text { work }\end{array}$ & $\begin{array}{l}\text { Pers. } \\
\text { work }\end{array}$ & $\begin{array}{l}\text { S. rol } \\
\text { play }\end{array}$ \\
\hline Formal lecture & $-0,5^{* *}$ & -- & -- & -- & -- & -- & -- & -- & -- \\
\hline Interactive lecture & -- & $-0,35^{* *}$ & -- & -- & -- & -- & -- & -- & -- \\
\hline $\begin{array}{l}\text { Student-centered } \\
\text { teaching }\end{array}$ & -- & -- & $-0,25^{* *}$ & -- & -- & -- & -- & -- & -- \\
\hline Student presentations & -- & -- & -- & $-0,22^{* *}$ & -- & -- & -- & -- & -- \\
\hline $\begin{array}{l}\text { Teaching around } \\
\text { group work }\end{array}$ & -- & -- & -- & -- & $-0,24 * *$ & -- & -- & -- & -- \\
\hline Tutorials & -- & -- & -- & -- & -- & $-0,19 *$ & -- & -- & -- \\
\hline Group work & -- & -- & -- & -- & -- & -- & $-0,24 * *$ & -- & -- \\
\hline Private study & -- & -- & -- & -- & -- & -- & -- & $-0,32^{* *}$ & -- \\
\hline Student role play & -- & -- & -- & -- & -- & -- & - & -- & $-0,33^{*}$ \\
\hline
\end{tabular}

\section{Results}

\section{Teaching Expectations and Preferences}

After analyzing frequencies of the most desired, most expected and most rejected methods which were assigned first place in their category, we see that the most desired teaching methods are the interactive lecture, student-centered instruction, and group work.
Notwithstanding, most participants $(60.2 \%)$ expect the formal lecture to be the method most used when a subject begins, followed by the interactive lecture and student-centered instruction. Teaching methods most rejected by participants are the formal lecture, student presentations and student role play. Finally, as for tutorials and private study, we can state that students neither expect these methods nor desire them, they rather reject them (Table 2).

Table2: Frequency of first-place responses in desired, expected and rejected forms of teaching.

\begin{tabular}{|l|l|l|l|}
\hline Teaching Method & Desired (\%) & Expected (\%) & Rejected (\%) \\
\hline Interactive lecture & $\mathbf{9 0 ( 3 0 . 6 )}$ & $82(27.8)$ & $2(0.7)$ \\
\hline Student-centered teaching & $80(27.2)$ & $12(4.1)$ & $5(1.7)$ \\
\hline Group work & $57(19.4)$ & $8(2.7)$ & $5(1.7)$ \\
\hline Teaching around group work & $20(6.8)$ & $5(1.7)$ & $10(3.4)$ \\
\hline Formal lecture & $15(4.9)$ & $\mathbf{1 7 7}(\mathbf{6 0 . 2})$ & $\mathbf{1 3 5}(\mathbf{5 0 )}$ \\
\hline Private study & $12(4.4)$ & $2(0.7)$ & $24(8.2)$ \\
\hline Student presentations & $7(2.4)$ & $6(2.5)$ & $52(17.7)$ \\
\hline Tutorials & $2(0.7)$ & $1(0.3)$ & $18(6.1)$ \\
\hline Student role play & $6(2)$ & $0(0)$ & $37(12.6)$ \\
\hline
\end{tabular}




Mean scores for desired, expected and rejected methods show that the most desired
methods (in descending order) are the interactive lecture $(\mathrm{X}=1.37 ; \mathrm{SD}=1,29)$, student-centered
instruction $(\mathrm{X}=1.23 ; \mathrm{SD}=1,28)$ and group work $(\mathrm{X}=1.20 ; \mathrm{SD}=1,16)$. The methods most
expected are the formal lecture $(\mathrm{X}=2.18 ; \mathrm{SD}=1,17)$ and the interactive lecture $(\mathrm{X}=1.58$;
$\mathrm{SD}=1,2)$. At the same time, formal lecture is also the method most rejected ( $\mathrm{X}=1.68$;
$\mathrm{SD}=1,34)$, followed by student presentations $(\mathrm{X}=1.03 ; \mathrm{SD}=1,18)$ and student role play
$(\mathrm{X}=0.99 ; \mathrm{SD}=1,1)$.

Table 3 shows frequencies of the most effective evaluation methods, as indicated by being assigned first place. The means for the most effective evalu- ation methods according to participants are: daily work $(\mathrm{X}=1.92 ; \quad \mathrm{SD}=1,22)$ and tests $(\mathrm{X}=1.00$; $\mathrm{SD}=1,12)$.

Table 3: Frequency of evaluation methods being assigned first place

\begin{tabular}{|l|l|}
\hline Evaluation method & First place: N (\%) \\
\hline Daily work & $\mathbf{1 4 5}(\mathbf{4 9 . 3 )}$ \\
\hline Tests & $47(16)$ \\
\hline Research projects & $45(15.3)$ \\
\hline Essays & $26(8.8)$ \\
\hline Oral presentations & $11(3.7)$ \\
\hline Lab work & $11(3.7)$ \\
\hline Problems/exercises & $2(0.7)$ \\
\hline Poster presentations & $5(1.7)$ \\
\hline Calculation exercises & $1(0.3)$ \\
\hline
\end{tabular}

Participants rated teacher qualities such that teaching skills $(X=3.96 ; \mathrm{SD}=1,31)$ and knowledge of the material $(\mathrm{X}=3.25 ; \mathrm{SD}=1,15)$ were considered most important. By contrast, enthusiasm $(\mathrm{X}=2.63$; $\mathrm{SD}=1,44)$ and organization $(X=2.46 ; S D=1,17)$ were the least valued qualities. Teacher accessibility $(X=2.96$; $\mathrm{SD}=1,41$ ) was ranked in the middle, being considered neither very important nor unimportant.

\section{Age and Expectations}

Teaching expectations as a function of age were analyzed using Spearman correlations. Results show that some of the most positive teaching methods and teacher qualities correlate significantly with age, although the correlations are low. Among desired teaching methods, it can be observed that the older the participants, the more they prefer private study and tutorials methods. As for undesirable methods, it can be seen that the older the participants, the more they reject student-centered instruction and the less they reject private study. Finally, we can also observe that the older the participants, the less they value enthusiasm as a teacher quality (Table 4). 
Table 4: Correlations between teaching expectations and age $\left(\mathbf{p}<0,01:^{* *} ; \mathbf{p}<0,05:^{*}\right)$.

\begin{tabular}{|l|l|}
\hline & $\mathrm{r}$ \\
\hline Desirable teaching & \\
\hline Private study & $.12^{* *}$ \\
\hline Tutorials & $.16^{* *}$ \\
\hline Undesirable teaching & \\
\hline Student-centered instruction & $.12^{*}$ \\
\hline Private study & $-.13^{*}$ \\
\hline Qualities of a good teacher & \\
\hline Enthusiasm & $-.15^{*}$ \\
\hline
\end{tabular}

\section{Expectations and Student Gender}

Analysis of the relationship between teaching expectations and student gender was carried out using the Mann-Whitney U test. Results reveal significant differences in means between male and female students in some teaching methods and evaluation methods. However, differences were not found with regard to teacher qualities.
Regarding analysis of methods desired, male students prefer tutorials more than female students. In methods expected, male students expect more student-centered teaching. In methods rejected, female students reject student presentations to a greater degree than do male students (Table 5).

The most effective evaluation method for men was essays, for women it was daily work (Table 5).

Table 5: Differences between expectations of teaching according to student gender $(\mathbf{p}<0,05: *)$.

\begin{tabular}{|c|c|c|c|}
\hline Methods & Male Students & Female Students & $\mathbf{U}$ \\
\hline \multicolumn{4}{|l|}{ Teaching desired } \\
\hline Tutorials & 161.79 & 143.95 & $6368^{*}$ \\
\hline \multicolumn{4}{|l|}{ Teaching expected } \\
\hline Student-centered instruction & 165.37 & 142.17 & $5955^{*}$ \\
\hline \multicolumn{4}{|l|}{ Teaching not desired } \\
\hline Student presentations & 127.21 & 151.7 & 5934* \\
\hline \multicolumn{4}{|l|}{ Effective evaluation } \\
\hline Essay work & 136.91 & 114.63 & $5981 *$ \\
\hline Daily work & 124.94 & 152.92 & $5793 *$ \\
\hline
\end{tabular}

\section{Expectations and Teacher Gender}

Analysis of the relationship between students' expectations of teaching and teacher gender was also carried out using the Mann-Whitney U test. Results indicate that there are significant differences of means only among teaching methods that students expect with regard to teacher gender. There are no differences with regard to evaluation methods or teacher qualities (Table 6).

Students who work with male teachers expect the formal lecture significantly more. Students with female teachers expect more student presentations, group-based teaching and group work (Table 6).

Table 6: Differences between teaching expectations according to teacher's gender $\left(\mathbf{p}<0,01:^{* *} ; \mathbf{p}<0,05: *\right)$.

\begin{tabular}{|l|l|l|l|l|}
\hline \multicolumn{2}{|l|}{ Teaching expected } & Male Teachers & Female Teachers & U \\
\hline & Formal lecture & 157.66 & 126.51 & $8160^{* *}$ \\
\hline & Student presentations & 139.04 & 161.24 & $8658^{*}$ \\
\hline & Group-based teaching & 140.05 & 158.4 & $8835^{* *}$ \\
\hline & Group work & 138.22 & 162.58 & $8503^{* *}$ \\
\hline
\end{tabular}




\section{Conclusions}

\section{Expectations of Teaching}

Our results show little difference from those obtained previously by De la Fuente et al. (2004b), if we look only at the Granada sample. Participants in both studies choose teaching methods (desired, expected and rejected) and evaluation methods in the same order. However, differences lie in the degree of intensity with which teaching methods are accepted or rejected. Thus, in the study by De la Fuente et al. (2004b), means for methods desired and expected are higher than in our study, while at the same time means for rejected methods are lower.

As for value assigned to teacher qualities, both samples of students agree in rating teaching ability as the first quality, but they differ in rating the second quality. In this study we find knowledge of the material in second place, while in the study by De la Fuente et al. (2004b), teacher accessibility is rated second.

From the analysis of teaching and evaluation methods, several conclusions can be drawn. First, participants agree in that: (a) they prefer methodologies where the teacher has a mediating role (interactive lecture, student-centered teaching and group work); (b) they reject methodology in which the teacher directs and controls the entire teachinglearning process (formal lecture); and (c) they consider that the most effective evaluation method is one where students must play an active role and are more involved in their learning (daily work).

Second, the European Space for Higher Education Superior involves a change in the structure of university education, spanning everything from organization of degree programs to credit equivalencies. ECTS credits (European Credit Transfer System) modify the conception of the teaching-learning process; herein the methods of tutorials and private study take on importance, being essential to the new conception of university learning. But in our study, these methods are rejected by the students.

Differences are observed between methods desired, expected and rejected. On one hand, more than half the participants agree that they expect and reject the formal lecture as a method, perhaps inducing negative expectations of the teaching method, and consequently provoking students' demotivation and dissatisfaction with their university studies (James, 2001). They are expecting a type of teaching (the formal lecture) which they find not at all desirable, while they expect and desire interactive teaching, allowing us to conclude that what they most expect does not concur with what they most desire. We must underscore this fact, since, as several authors affirm (Darlaston-Jones et al., 2003; James, 2001; Sander et al., 2000), we may find ourselves before a self- fulfilling prophecy; that is, if persons act so as to fulfill what they expect will happen, students who expect to receive lecture classes will be reluctant to accept other teaching methodologies.

Students state that the most important qualities of a good teacher are teaching skills, followed by knowledge of the material. Students in general assign more importance to professional characteristics and less value to intra- and inter-personal skills, such as being accessible or having enthusiasm. Some research results (De la Fuente et al., 2004a and b; Sander et al., 2000) concur with our data, although differences do appear in other research, since they give more importance to interpersonal skills like communication or proximity to students (Chonko et al., 2002; McDowell \& McDowell, 1986), and to personal characteristics such as stimulating interest (Chonko et al., 2002) or being friendly (McDowell \& McDowell, 1986).

\section{Expectations of Teaching and Individual Differences}

Individual differences are observed in the analysis of teaching expectations, although not for all types of expectations. Thus, student age is related to the teaching desired, teaching rejected and to teacher qualities. As for student gender, differences are also observed in all types of expectations but not in what concerns teacher qualities. Teacher gender is related only to teaching expected.

With regard to relationships between age and expectations, based on correlations obtained we can specify certain changes. For example, we can conclude that the older the students, the more they prefer more individualized and autonomous instruction, such as private study and tutorials. Moreover, the older participants show more rejection toward student-centered instruction, and to a lesser extent, toward private study as well. Changes observed in relation to student age and expectations of teaching are not large ones, although results do show a certain relationship between age and expectations. We therefore consider that further research is necessary for better understanding the stability or instability of expectations over the length of one's education.

As for student gender, our data indicate that there are no differences in perception of desirable teacher qualities. This same result was found in the study by Miles and Gonsalvez (2003), although other research shows different results (McDowell \& McDowell, 1986; Smith et al., 1994).

There are gender differences among students when it comes to their manner of expecting, desiring and rejecting teaching and evaluation methods. Expectations of male students are oriented toward methods that require a more active role; thus they seem to 
have more individual, autonomous expectations than female students. Male students desire more tutorials, expect more student-centered instruction and consider evaluation through essay work to be more effective.

As for teacher gender, students expect more teaching methods that facilitate active learning (student presentations, group-based instruction and group work) from a female teacher; however, with a male teacher they expect teaching which does little to encourage active learning and is more focused on the formal lecture.

In general, we can conclude that participants prefer methods where the teacher is a mediator and that al- low the student an active role in his or her learning. However, complete autonomy is not desired, since they substantially reject student presentations, student role play, tutorials and private study, and give little value to essay work and oral presentations as methods for evaluation. This situation may indicate that the active role students seek does not yet correspond to autonomy and the full capacity to regulate their own learning. Therefore, we share in the opinion of those who call for more specific training and development in autonomy and self-regulated learning, both in pre-university education as well as at the university itself (De la Fuente et al., 2005; Vermunt, 2003).

\section{References}

Biggs, J. (2001). Teaching for Quality Learning at University ( $3^{\mathrm{a}}$ Ed.). Buckingham: Open University Press.

Chonko, L.B., Tanner, J.F. \& Davis, R. (2002). What are they thinking? Students' expectations and self-assessments. Journal of Education for Business, 77 (5), 271-281.

Darlaston-Jones, D., Pike, L., Cohen, L., Young, A., Haunold, S. \& Drew, N. (2003). Are they being served? Students' expectations of higher education. Issues in Educational Research, 13(1), 31-52. [http://education.curtin.edu.au/iier/iier13/darlaston-jones.html] (Accessed February 2004).

De la Fuente, J., Nievas, F. \& Rius, N. (2002). Cuestionario sobre las expectativas de enseñanza de los estudiantes universitarios. [Questionnaire on university students' expectations of teaching.] University of Almeria. Unpublished.

De la Fuente, J., Justicia, F., Cano, F., Martínez, J. M., Pichardo, M.C. \& Berbén, A.G. (2005). Self-regulated learning and regulated teaching in the European Space for Higher Education: contributions to the Biggs model. Presented at the 9th European Congress of Psychology. Granada (Spain), July 3-8, 2005.

De la Fuente, J., Justicia, F., Sander P., Cano, F., Martínez, J. M. \& Pichardo, M.C. (2004b). Evaluación de la percepción del proceso de enseñanza-aprendizaje en los alumnos universitarios. [Evaluation of university students' perception of the teaching-learning process.] Symposium presented at the VII Congreso Europeo de Evaluación Psicológica. Málaga (Spain), April 1-4, 2004.

De la Fuente, J., Sander P., Justicia, F., Cano, F., Martinez, J. M. \& Pichardo, M.C. (2004a). Estudio de los procesos de enseñanza-aprendizaje en el marco del Espacio Europeo de Educación Superior (EEES). [Study of teachinglearning processes in the framework of the European Space for Higher Education (ESHE).] Symposium presented at the VII Congreso Internacional de Psicología y Educación. Almería ( Spain), March 30 - April 2, 2004.

Entwistle, N. (2000). ETL project. Enhancing Teaching-Learning Environments in Undergraduate Courses. [http://www.ed.ac.uk/etl] (Accessed March 2005)

James, R. (2001). Students' changing expectations of higher education and the consequences of mismatches with the reality. Presented at the OECD-IMHE conference, Management responses to changing student expectation. QUT, 24 September 2001

Keogh, K.M. \& Stevenson, K. (2001). Student expectations of tutor support: An expectations led quality assurance model. Presented at the ICDE Congress, Dusseldorf, April 2001.

Licata, J.W. \& Maxham, J.G. (1999). Student expectations of the university experience: Levels and antecedent for pre-entry freshmen. Journal of Marketing for Higher Education, 9(1), 69-91.

McDowell, E.E. \& McDowell, C.E. (1986). A Study of High School Students' Expectations of the Teaching Style of Male, Female, English and Science Instructors. Presented at the Annual Meeting of the International Communication Association. Chicago, IL, May 22-26.

Miles, W.M. \& Gonsalves, S. (2003). What you don't know can hurt you: students' perceptions of professors' annoying teaching habits. College Student Journal, 37(3), 447-455.

Ruzich, C.M. (1995). Are you my mother? Students' expectations of teachers and teachings related to faculty gender. Presented at the 46 th Annual Meeting of the Conference on College Composition and Comunication, Washington, DC., March 23-25, 1995.

Sander, P. (2005). Researching our students for more effective university teaching. Electronic Journal of Research in Educational Psychology, 5, (3), 113-130.

Sander, P., Stevenson, K., King, M. \& Coates, D. (2000). University Students' Expectations of Teaching. Studies in Higher Education, 25 (3), 309-323.

Smith, S., Medendorp, C.L., Ranck, S., Morison, K. y Kopfman, J. (1994). The prototypical features of the ideal professor from the female and male undergraduate perspective: the role of verbal and nonverbal communication. Journal on Excellence in College Teaching, 5, 5-22.

Stevenson, K. \& Sander, P. (1998). How do Open University students expect to be taught at tutorials? Open Learning, 13(2), 42-46. 
Stevenson, K., Sander, P. \& Naylor, P. (1997). ELPO - a model that uses student feedback to develop effective open tutoring. Open Learning, 12(2), 54-59.

Vermetten, Y.J., Vermunt, J.D. \& Lodewijks, H.G. (2002). Powerful learning environments? How university students differ in their response to instructional measures. Learning and Instruction, 12, 263-284.

Vermunt, J.D. (2003). The power of learning environments and the quality of student learning. In E. De Corte, L. Verschaffel, N.Entwistle \& J. van Merriënboer (Eds.), Powerful Learning Environments: Unravelling Basic Components and Dimensions. London: Pergamon \& Earli.

Yanhong, R. \& Kaye, M. (1999). Measuring service quality in the context of teaching: a study on the longitudinal nature of students' expectations and perceptions. Innovations in Education and Training International, 36(2), 145-154.

\section{Annex}

Type of teaching and learning styles (Sander, Stevenson, King \& Coates, 2000, p. 313)

\begin{tabular}{|l|l|}
\hline Formal lecture & \multicolumn{1}{|c|}{$\begin{array}{l}\text { The teacher will deliver a set presentation. Students will listen and take notes or } \\
\text { be given a set of notes. }\end{array}$} \\
\hline Interactive lecture & $\begin{array}{l}\text { The teacher will deliver a set presentation. Students will listen and take, or be given, } \\
\text { notes. Questions will be invited and responded to. Students may be required to under- } \\
\text { take exercises to check on their progress. }\end{array}$ \\
\hline $\begin{array}{l}\text { Student centered teach- } \\
\text { ing }\end{array}$ & $\begin{array}{l}\text { The teacher will have a presentation prepared, but prefers to be led by the student's } \\
\text { responses to questions, in what is actually delivered, and how. Students are encouraged } \\
\text { to think and participate. Extensive note taking is unlikely to be encouraged. }\end{array}$ \\
\hline Student presentations & $\begin{array}{l}\text { The students will prepare a set topic each and deliver it to their peers under the guidance } \\
\text { of the teacher. }\end{array}$ \\
\hline Teaching session \\
around group work & $\begin{array}{l}\text { The teacher has prepared a series of exercises or activities which are aimed at facilit- } \\
\text { ating students achieving the objectives of the session themselves. There will be very } \\
\text { little "formal" teaching }\end{array}$ \\
\hline Tutorials & $\begin{array}{l}\text { Students are set work to prepare, which is analyzed and considered in small group } \\
\text { settings. }\end{array}$ \\
\hline Student role play & $\begin{array}{l}\text { The teacher has prepared a series of exercises (brainstorm, discussion) or activities } \\
\text { (practicals, library projects) which are aimed at facilitating students achieving the ob- } \\
\text { jectives of the session themselves. There will be no "formal" teaching. All learning } \\
\text { will be through activity. }\end{array}$ \\
\hline Private study & $\begin{array}{l}\text { Students are given a list of readings, exercises and activities and left to get on with it. } \\
\text { There may be tutorial support from the teacher. }\end{array}$ \\
\hline and subsequently analyzed. \\
\hline aronts are asked to act out a situation or encounter which is watched by other students \\
\hline
\end{tabular}

\section{About the Authors}

Prof. Fernando Justicia Justicia

University of Granada, Spain

Jesús de la Fuente Arias

Universidad de Almería, Spain

M.Carmen Pichardo Martinez

University of Granada, Spain

Ms Ana Belen Garcia Berben

Becaria de Investigacion del Ministerio de Educación y Ciencia de España 
EDITORS

Mary Kalantzis, RMIT University, Australia.

Bill Cope, Common Ground, Australia.

EDITORIAL ADVISORY BOARD

Michael Apple, University of Wisconsin-Madison, USA.

David Barton, Lancaster University, UK.

James Paul Gee, University of Wisconsin-Madison, USA.

Brian Street, King's College, University of London, UK.

Kris Gutierrez, University of California, Los Angeles, USA.

Scott Poynting, University of Western Sydney, Australia.

Gunther Kress, Institute of Education, University of London.

Ruth Finnegan, Open University, UK.

Roz Ivanic, Lancaster University, UK.

Colin Lankshear, James Cook University, Australia.

Michele Knobel, Montclair State University, New Jersey, USA.

Nicola Yelland, RMIT University, Australia.

Sarah Michaels, Clark University, Massachusetts, USA.

Richard Sohmer, Clark University, Massachusetts, USA.

Paul James, RMIT University, Melbourne, Australia.

Michel Singh, University of Western Sydney, Australia.

Peter Kell, University of Wollongong, Australia.

Gella Varnava-Skoura, National and Kapodistrian University of Athens, Greece.

Andeas Kazamias, University of Wisconsin, Madison, USA

Ambigapathy Pandian, Universiti Sains Malaysia, Penang, Malaysia.

Giorgos Tsiakalos, Aristotle University of Thessaloniki, Greece.

Carey Jewitt, Institute of Education, University of London, UK.

Denise Newfield, University of Witwatersrand, South Africa.

Pippa Stein, University of Witwatersrand, South Africa.

Zhou Zuoyu, School of Education, Beijing Normal University, China.

Wang Yingjie, School of Education, Beijing Normal University, China.

Juana M. Sancho Gil, University of Barcelona, Spain.

Manuela du Bois-Reymond, Universiteit Leiden, Netherlands.

Mario Bello, University of Science, Technology and Environment, Cuba.

Miguel A. Pereyra, University of Granada, Spain.

José-Luis Ortega, University of Granada, Spain.

Daniel Madrid Fernandez, University of Granada, Spain.

Francisco Fernandez Palomares, University of Granada, Spain.

ASSOCIATE EDITORS, 2005

Visit: http://www.Learning-Journal.com

SCOPE AND CONCERNS

Visit: http://www.Learning-Journal.com

SUBMISSION GUIDELINES

Visit: http://www.Learning-Journal.com

INQUIRIES

Email: cg-support@commongroundpublishing.com 